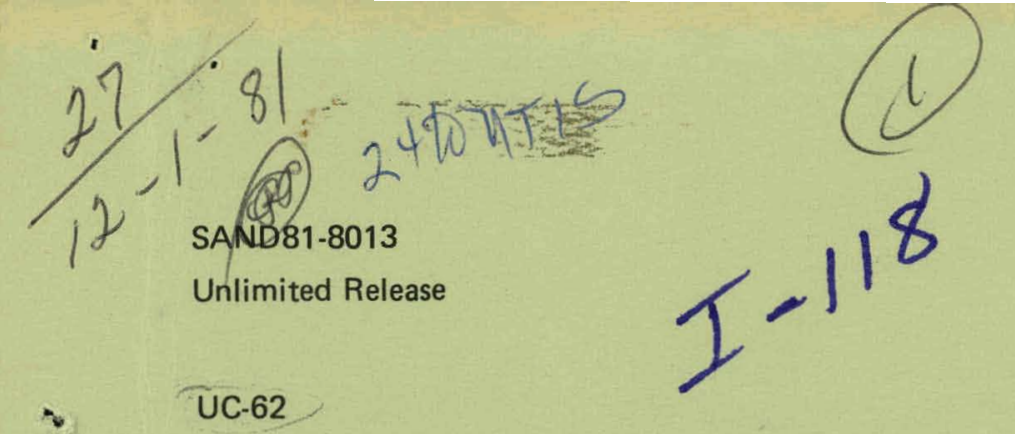

\title{
A Solid-Electrolyte Oxide-Ion Electrode For Molten Nitrates
}

\author{
D. A. Nissen
}

Prepared by Sandia National Laboratories, Albuquerque, New Mexico 87185 and Livermore, California 94550 for the United States Department of Energy under Contract DE-AC04-76DP00789.

Printed October 1981 


\section{DISCLAIMER}

This report was prepared as an account of work sponsored by an agency of the United States Government. Neither the United States Government nor any agency Thereof, nor any of their employees, makes any warranty, express or implied, or assumes any legal liability or responsibility for the accuracy, completeness, or usefulness of any information, apparatus, product, or process disclosed, or represents that its use would not infringe privately owned rights. Reference herein to any specific commercial product, process, or service by trade name, trademark, manufacturer, or otherwise does not necessarily constitute or imply its endorsement, recommendation, or favoring by the United States Government or any agency thereof. The views and opinions of authors expressed herein do not necessarily state or reflect those of the United States Government or any agency thereof. 


\section{DISCLAIMER}

Portions of this document may be illegible in electronic image products. Images are produced from the best available original document. 
Issued by Sandia National Laboratories, operated for the United States Department of tnergy by Sandia Corporation.

\section{NOTICE}

This report was prepared as an account of work sponsored by the United States Government. Neither the United States nor the United States Department of Energy, nor any of their employees, makes any warranty, express or implied, or assumes any legal liability to responsibility for the accuracy, completeness or usefulness of any information, apparatus, product or process disclosed, or represents that its use would not infringe privately owned rights.

Printed in the United States of America

Available from

National Technical Information Service

U. S. Department of Commerce

5285 Port Royal Road

Springfield, VA 22161

Price: Printed C.nny $\$ 1.50$; Micrnfirhe $\$ 3.00$ 


\section{PAGES 1 to 2 WERE INTENTIONALLY LEFT BLANK}


SAND81-8013

Unlimited Release

Printed October 1981

\title{
A SOLID $A$ ELECTROLYTE OXIDE-ION ELECTRODE FOR MOLTEN NITRATES
}

\author{
D. A. Nissen \\ Exploratory Chemistry Division I \\ Sandia National Laboratories, Livermore $251 / 238$
}

ABSTRACT

An oxide ion sensitive electrode of the type $\mathrm{Pb}, \mathrm{PbO} / \mathrm{ZrO}_{2}\left(\mathrm{Y}_{2} \mathrm{O}_{3}\right) / /$ was constructed and its performance tested in the binary, equimolar molten salt $\mathrm{NaNO}_{3}-\mathrm{KNO}_{3}$ over the temperature range $336-350^{\circ} \mathrm{C}$. The response of this electrode to oxide ion concentrations over the range $10-6-10-10$ moles $/ \mathrm{kg}$ is linearly dependent upon $\log \left[0^{=}\right]$, and $\mathrm{dE} / \mathrm{dlog}\left[\mathrm{O}^{=}\right]$corresponds to a two-electron process.

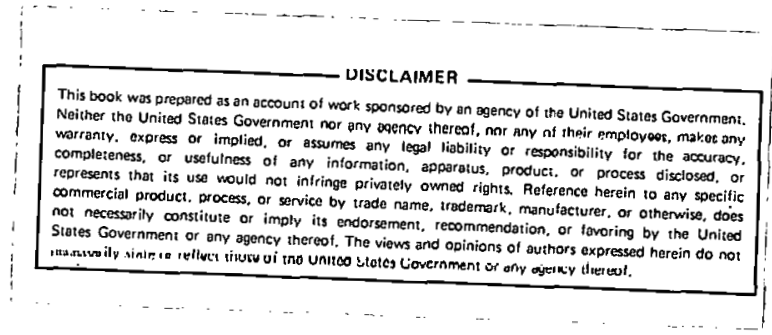




\section{CONTENTS}

Page

Introduction

9

Experimental Procedure 12

Results and Discussion 14

Conclusion 18

References 19 


\section{ILLUSTRATIONS}

Figure

$\underline{\text { Page }}$

1. Experimental Cell and Reference Electrode

13

2. $\mathrm{Pb}, \mathrm{PbO}$ Indicator Electrode Potential vs. $\log \frac{\left(\mathrm{CrO}_{4}=\right)^{2}}{\left(\mathrm{Cr}_{2} \mathrm{O}_{7}=\right)}$

15

3. Titration Curve of Dichromate with Carbonate 


\section{A SOLID ELECTROLYTE OXIDE ION ELECTRODE FOR MOLTEN NITRATES}

\section{Introduction}

oxide ion conducting ceramics such as stabilized zirconia have assumed increased scientific interest and technical significance in recent years as solid electrolytes. Indicator electrodes employing zirconia stabilized with $\mathrm{CaO}, \mathrm{MgO}$, or $\mathrm{Y}_{2} \mathrm{O}_{3}$ have been used in the metallurgical industry to measure oxygen activity in gases and molten metals. They have also been used in laboratory research to determine the dissociation pressure of solid oxides, the solubility of oxygen in liquid metals, and the oxide ion activity in molten salts and glasses.

The introduction of 10-20 at. percent of the oxides of lower valent cations such as $\mathrm{Ca}^{+2}$ or $\mathrm{\gamma}+3$, stabilizes the cubic fluorite structure of $\mathrm{ZrO}_{2}$ and leads to the formation of anion vacancies in order to maintain charge neutrality. 0xide ion conduction then occurs through this onedimensional structurel.

Stabilized zirconia can function as a semi-permeable membrane in molten salts, and is able to transport oxide ions into and out of these liquids? The reversibility of the process

$$
0=\left(\mathrm{ZrO}_{2}\right) \leftrightharpoons 0=(\ell)
$$

has been demonstrated under potentiometric conditions, i.e. when very small currents are passed as, for example, when stabilized zirconia forms part of an indicator electrodel,2. Electrodes employing stabilized zirconia, and which are sensitive to the concentration of oxide ions, have been described 3,4 .

The oxide ion sensitive electrode used in this study is one where the oxygen partial pressure is fixed by a metal-metal oxide couple. The electrode may be represented as

$$
\mathrm{Pb}, \mathrm{PbO} / \mathrm{ZrO}_{2}\left(\mathrm{Y}_{2} \mathrm{O}_{3}\right) / /
$$

where the double line represents the zirconia membrane that separates the electrode from the bulk melt. In this case the electrode reaction is

$$
2 e^{-}+1 / 20_{2} \leftrightharpoons 0^{=}
$$




$$
E=E^{0}-\frac{R T}{2 F} \ln \frac{a_{0}=}{P_{0_{2}}}
$$

Since the oxygen partial pressure is fixed by the $\mathrm{Pb}$, Pb0 equilibrium the constant terms can be incorporated into $E_{0}$ and equation 3 reduces to

$$
E=E^{0}-\frac{R T}{2 F} \ln \mathrm{aO}_{0}=
$$

As a consequence of the gradient in oxide ion activity across the zirconia membrane a potential is developed which is given by

$$
E=\frac{-R T}{2 F} \ln \frac{\left(a_{0}=\right)_{1}}{\left(a_{0}=\right)_{2}}
$$

where 1 and 2 correspond to the inside and outside of the zirconia membrane, respectively. It is assumed in equation (5) that the zirconia membrane functions in a manner analogous to a liquid junction and that the transport number of the oxide ion equals one.5,8 Therefore, the potential of electrode (a), with respect to the reference electrode, is given by

$$
E=E^{0}-\frac{R T}{2 F} \ln \left(a_{0}=\right)_{1}-\frac{R T}{2 F} \ln \frac{\left(a_{0}=\right)_{1}}{\left(a_{0}=\right)_{2}}
$$

Since the oxide ion activity inside the zirconia membrane is fixed, these terms may be incorporated with $E^{\circ}$ to give

$$
E=E O^{\prime}+\frac{R T}{? T} \ln \left(\dot{a}_{(1=)}\right) \text { ? }
$$

Thus, the potential of electrode (a) can be directly related to the activity of the oxide ion in the $\mathrm{NaNO}_{3}-\mathrm{KNO}_{3}$ melt.

While the electrode potential is a measure of the activity of the oxide ion, equation (7), it is not possible to associate a particular cell emf with a specific oxide ion activity unless an independently determined value of $E^{\circ}$, the standard electrode potential, as well as phase boundary potentials are available. At the present state of knowledge in molten salts these data are generally not available. However, in this study we are primarily concerned with the response of the $\mathrm{Pb}, \mathrm{PbO} / \mathrm{ZrO}_{2}$ electrode to changes in the oxide ion concentration rather than its absolute value. Thus we shall, as a first approximation, assume that the $\mathrm{Pb}, \mathrm{PbO} / \mathrm{ZrO}_{2}$ electrode potential is a measure of the oxide ion concentration.

Metal-metal oxide electrodes like (a) have been used quite successfully in both research and industrial applications. Generally, the most frequently used metal-metal oxide couples are $\mathrm{Cu}-\mathrm{Cu}_{2} \mathrm{O}$, Fe-FeO, $\mathrm{Ni}-\mathrm{NiO}$, or $\mathrm{Pb}-\mathrm{PbO}$ (other couples are also possible) 4 . For our experiments we chose the Pb-Pb0 couple because this particular couple has been investigated extensively. The electrode process is unambiguous and reversible and the mutual solubility of the 
reproducibility of the electrode at low temperature $\left(350^{\circ} \mathrm{C}\right)$ should be improved by the presence of a liquid phase $\left(\mathrm{Pb}, \mathrm{m}, \mathrm{p}, 327^{\circ} \mathrm{C}\right)$.

In order to evaluate the response of the $\mathrm{Pb}, \mathrm{PbO} / \mathrm{ZrO}_{2}$ electrode it was necessary to vary the oxide ion concentration of the $\mathrm{NaNO}_{3}-\mathrm{KNO}_{3}$ melt in a systematic manner. Typically, this is done by adding weighed amounts of $\mathrm{Na}_{2} \mathrm{O}$. However, this approach was not taken for several reasons: $\mathrm{Na}_{2} \mathrm{O}$ is very difficult to obtain commercially in high purity (typically it is 95-97 percent pure), even $\mathrm{Na}_{2} \mathrm{O}$ synthesized in the laboratory under carefully controlled conditions contains several percent $\mathrm{Na}_{2} \mathrm{O}_{2}{ }_{7}$; $\mathrm{Na}_{2} \mathrm{O}$ is hydroscopic and difficult to maintain unreacted in other than inert atmospheres. Evidence has recently appeared indicating that even in the absence of molecular oxygen oxide ions may react with molten alkali nitrates (at temperatures below $350^{\circ} \mathrm{C}$ ) to form peroxide and superoxide ions $5,8,9$

$$
\begin{aligned}
& \mathrm{O}^{=}+\mathrm{NO}_{3}^{-} \leftrightharpoons \mathrm{O}_{2}=+\mathrm{NO}_{2}^{-} \\
& \mathrm{O}_{2}=+2 \mathrm{NO}_{3}^{-} \leftrightharpoons 2 \mathrm{O}_{2}^{-}+2 \mathrm{NO}_{2}^{-}
\end{aligned}
$$

Therefore, the approach taken here was to establish a known oxide ion concentration by means of a Lux-Flood acid-base reaction

$$
A+0=\leftrightharpoons B
$$

where $A$ and $B$ are the conjugate acid-base pair, e.g.

$$
\begin{aligned}
& \mathrm{CO}_{2}+0=\leftrightharpoons \mathrm{CO}_{3}= \\
& \mathrm{SiO}_{2}+0=\mathrm{SiO}_{3}=
\end{aligned}
$$

In the Lux-Flood acid-base concept an acid is an oxide ion acceptor and a base is an oxide ion donor10,11. In these experiments the oxide ion concentration was determined by the chromate-dichromate equilibrium

$$
\mathrm{Cr}_{2} \mathrm{O}_{7}=+\mathrm{O}=\leftrightharpoons 2 \mathrm{CrO}_{4}=
$$

That is,

$$
[0=]=\frac{\left[\mathrm{CrO}_{4}=\right]^{2}}{\left[\mathrm{Cr}_{2} \mathrm{O}_{7}=\right] \mathrm{K}}
$$

where $K$ is the equilibrium constant for reaction (13) in the $\mathrm{NaNO}_{3}-\mathrm{KNO}_{3}$ 
melt. Thus, the oxide ion concentration is uniquely determined by the ratio of chromate to dichromate, equation (14). Strictly speaking, eqn. (14) should be written in terms of the activities of its components. However, the equilibrium constants reported by Kust 12 for reaction (13) were calculated from concentrations. It is entirely self-consistent therefore, to use eqn. (14) to calculate oxide ion concentrations. It is only necessary to assume that the activity coefficients are independent of concentration which seems reasonable in solutions this dilute $\left(<10^{-1} \mathrm{~mole} / \mathrm{kg}\right)$. Reaction (13) has been well characterized in $\mathrm{NaNO}_{3}-\mathrm{KNO}_{3}$ and there appear to be no side reactions of any consequence below $350^{\circ} \mathrm{C} 12$.

\section{Experimental Procedure}

The cell used to measure changes in oxide ion concentration of the $\mathrm{NaNO}_{3}-\mathrm{KNO}_{3}$ may be represented as

$$
\mathrm{Pb}, \mathrm{PbO} / \mathrm{ZrO}_{2}\left(\mathrm{Y}_{2} \mathrm{O}_{3}\right) / / \mathrm{NaNO}_{3}-\mathrm{KNO}_{3} / \mathrm{AgNO}_{3}(0.1 \mathrm{molal}), \mathrm{NaNO}_{3}-\mathrm{KNO} \mathrm{N}_{3}, \mathrm{Ag}
$$

where the double line represents the zirconia membrane. The $\mathrm{Ag}, \mathrm{AgNO}_{3}$ reference electrode, used to monitor the potential of the $\mathrm{Pb}$, PbO electrode, was contained in a thin Pyrex membrane. Because it exhibits ideal Nernst behavior and the metal has no observable tendency to dissolve in molten silver and is highly reversible to its ions, the $\mathrm{Ag}, \mathrm{AgNO}_{3}$ electrode has been used extensively in molten nitrates as a reference electrode.13,14 The $\mathrm{Pb}, \mathrm{PbO}$ electrode was contained in a closed end stabilized zirconia tube (corning Glass Wurks, Solon, Ohio) one-half inch in diameter and 12 inches long. Three different compositions were tried: $\mathrm{LrU}_{2}-8$ wt. percent $\mathrm{Y}_{2} \mathrm{O}_{3}$, and $\mathrm{ZrO}_{2}-3$ wl. percent $\mathrm{MgO}_{\mathrm{g}}$ and $T h 0_{2}=15$ wt. percent $\mathrm{Y}_{2} \mathrm{O}_{3}$. No difference in elert.rmchemical behavior was detected. All these compositions exhibited excellent thermal shock resistance and appeared visually to be unattacked by immersion in the nitrate melt at $350^{\circ} \mathrm{C}$ for periods of up to 14 days.

The $\mathrm{Pb}, \mathrm{Pb0}$ electrode was made by mixing together approxiliately equal volumes of $99.9 \%$ pure $\mathrm{Pb}$ shavings and the tetragonal form of Pb0, litharge. Connection to the $\mathrm{Pb}$, $\mathrm{PbO}$ electrode was made by a 304 stainless steel rod. Visually the rod appeared to be unattacked by the PL, Pb0 mixture and the constancy and reproducibility of the EMF measurements seemed to confirm this. The stainless steel rod was held in place by an 0-ring compression seal that al so served to maintain atmospheric integrity.

Figure 1 , is an illustration of the experimental apparatus and the $\mathrm{Pb}, \mathrm{Pb} 0$ electrode. In order to avoid any reaction between the nitrate melt and the container that might affect the results, the melts were held in a gold crucible. The chromel-alumel thermocouple used to monitor the melt temperature was

sheathed in gold. 


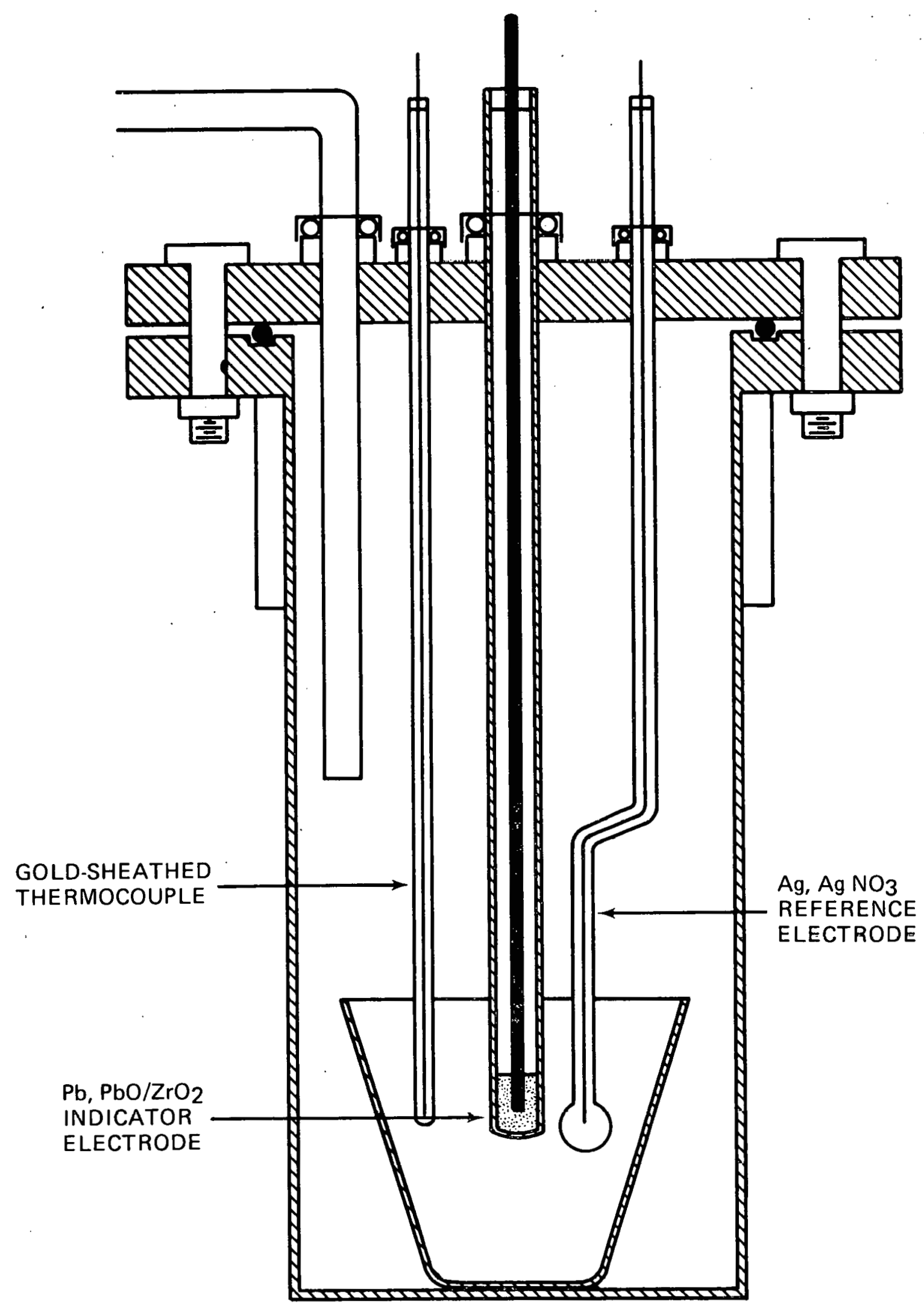

Figure 1. Experimental Cell and Reference Electrode 
Argon was used in this study to provide an inert, controlled atmosphere over the melt. It was carefully purified by passage through an $800^{\circ} \mathrm{C}$ titanium bed to remove oxygen and water and then through an Ascarite column to remove any carbon dioxide. To prevent back-diffusion of atmospheric gases, the effluent gas was also passed through a sulfurlc acld bubbler. In addition to careful purification of the gases, all the salts used in this program were routinely purified by recrystallization from distilled water. Following the recrystallization operation the salts were stored in a vacuum oven at $150^{\circ} \mathrm{C}$.

The potential between the $\mathrm{Pb}, \mathrm{PbO}$ indicator electrode and the $\mathrm{Ag}, \mathrm{AgNO}_{3}$ reference electrode was measured with a high impedance electrometer (Keithley Model 616). The output from the electrometer was recorded on a Hewlett-Packard Model $7100 \mathrm{~B}$ strip chart recorder.

In order to establish a particular oxide ion concentration the appropriate weighed quantities of vacuum-dried $\mathrm{K}_{2} \mathrm{CrO}_{4}$ and $\mathrm{K}_{2} \mathrm{Cr}_{2} \mathrm{O}_{7}$ were added to the melt and argon was bubbled through the melt to help establish a uniform concentration. Changes in the oxide ion concentration could be made by adding weighed amounts of either $\mathrm{K}_{2} \mathrm{CrO}_{4}$ or $\mathrm{K}_{2} \mathrm{Cr}_{2} \mathrm{O}_{7}$ depending upon the change desired. The solutions were kept relatively dilute with the $\mathrm{CrO}_{4}=$ and $\mathrm{Cr}_{2} \mathrm{O}_{7}=$ concentrations varying between $5 \times 10^{-1}-3 \times 10^{-5} \mathrm{moles} / \mathrm{kg}$ 。

Fxrept. for the lowest oxide ion concentration ( $<10-12 \mathrm{moles} / \mathrm{kg}$ ) the response of the $\mathrm{Pb}, \mathrm{PbO} / \mathrm{ZrO}_{2}$ electrode to changes in the oxide ion concentration was very rapid. Once the equilibrium potential had been reached $(\sim 5-10$ min) it remained very stable $( \pm 0.0005 \mathrm{~V})$ for as long as 48 hours. At the lower oxide ion concentrations about an hour was required for the potential to stabilize.

Results and Discussion

The results of 60 experiments in which the response of the $\mathrm{Pb}, \mathrm{PbO}_{2} / \mathrm{ZrO}_{2}$ electrode to variations in the oxide ion concentration of a $\mathrm{NaNO}_{3}-\mathrm{KNO}_{3}$ melt, as determined by the $\mathrm{CrO}_{4}=/ \mathrm{Cr}_{2} \mathrm{O}_{7}=$ ratio, are shown in Figure 2. Also included are the relevant oxide ion concentrations calculated from equation (14). To aid in interpretation of the data presented in this Figure all the potential values for a given concentration have been averaged. The spread is $\pm U . U U b V$.

Over the oxide ion concentration range $10^{-10}$ to $10^{-6} \mathrm{moles} / \mathrm{kg}$ the $\mathrm{Pb}$, $\mathrm{PbO} / \mathrm{ZrO}_{2}$ electrode potential is a linear function of the logarithm of the nxide ion concentration with a slope equal $2.3 \mathrm{RT} / 2 \mathrm{~F}$. As the oxide ion concentration falls below $10-10$ moles/kg the indicator electrode potentid begins to show a pronounced departure from this relationship. At oxide ion concentrations below $10^{-12}$ moles $/ \mathrm{kg}$ the $\mathrm{Pb}, \mathrm{PbO} / \mathrm{ZrO}_{2}$ electrode potential appears to be invariant with concentration. While lines of differing slope may. be drawn through the data shown in Figure 2 to include more of the data points, the precision of the measurements is such that this treatment of the data is unjustified. 


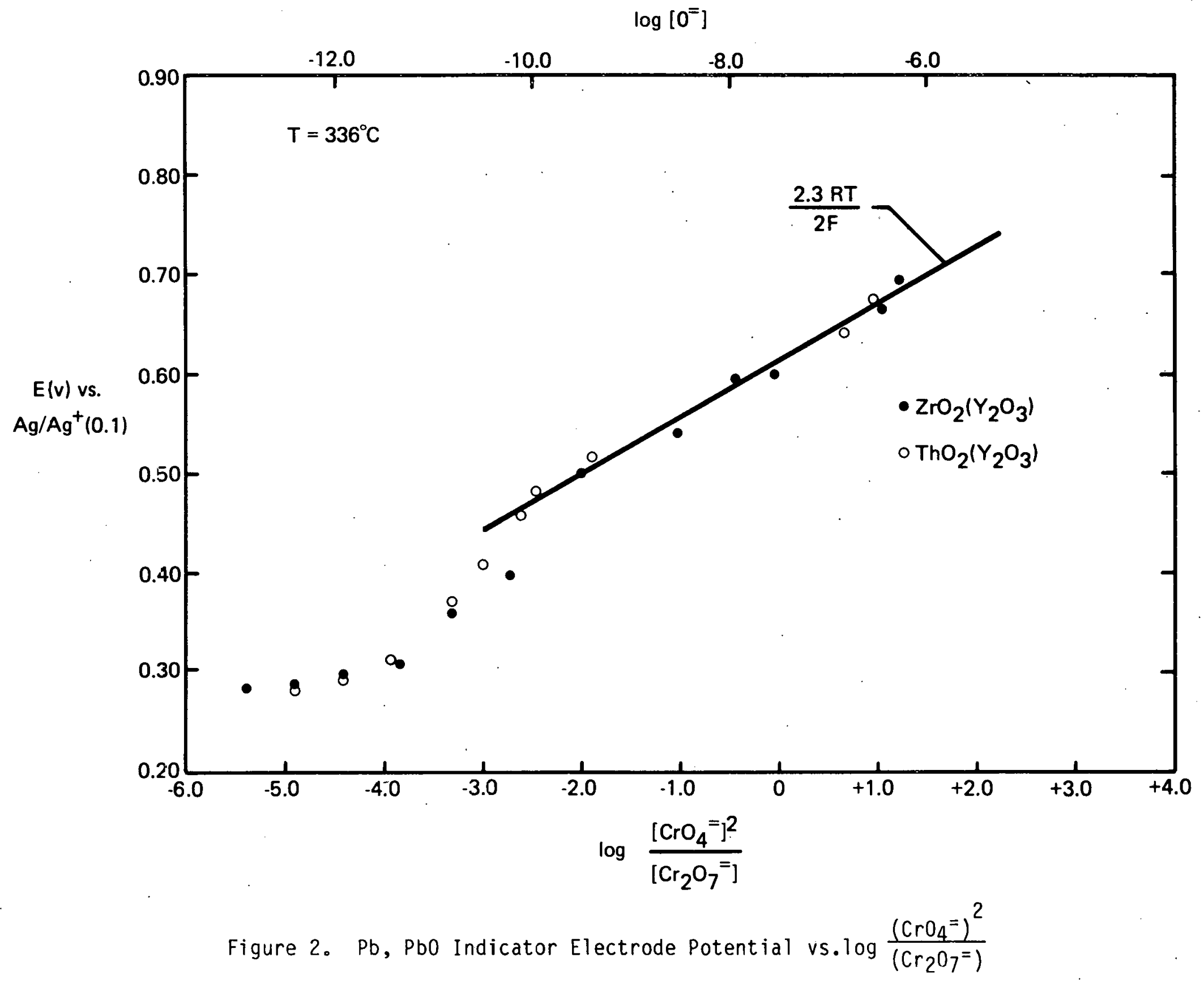


If equation (2) represents the potential determining reaction that takes place at the $\mathrm{Pb}, \mathrm{PbO} / \mathrm{ZrO}_{2}$ electrode a slope of $2.3 \mathrm{RT} / 2 \mathrm{~F}$ would be expected. The question then is, why does the concentration dependence of the $\mathrm{Pb}, \mathrm{PbO}$ electrode potential change when the oxide ion concentration falls below 10-iU moles/kg? Since the dichromate concentration at this oxide ion rnncentration is $\sim 10^{-3}$ moles/kg significant changes in its activity coefficient are considered unlikely. It is possible that at very low oxide ion concentrations ( $<10-10$ moles $/ \mathrm{kg})$ reactions which cause a decrease in the oxide ion concentrations and whose products are undetectable by the $\mathrm{Pb}, \mathrm{PbO} / \mathrm{ZrO}_{2}$ electrode, begin to become significant. As a consequence, the oxide ion concentration is actually lower than would be predicted from equation (7). As the nominal oxide ion concentration falls below $10-12$ moles $/ \mathrm{kg}$ essentially all of it is converted to a species undetectable by the $\mathrm{Pb}, \mathrm{PbO} / \mathrm{ZrO}_{2}$ electrode and consequently the electrode potential becomes invariant with changes in the nominal oxide ion concentration. Reactions such as

$$
\begin{aligned}
& 0=+1 / 20_{2} \leftrightharpoons 0_{2}= \\
& 0=+3 / 20_{2} \leftrightharpoons 20_{2}^{-}
\end{aligned}
$$

in which the oxide ion reacts with small amounts of oxyyen in the melt may be responsible. These reactions are particularly credible in light of Stern's observation that zirconia-based electrodes are apparently only responsive to changes in the oxide ion concentration.5,15 The activity coefficient of the oxide ion in this melt, while unknown, appears to be reasonably constant over the concentration range 10-10 $-10^{-6}$ mole/kg because of the linear variation of potential with concentration.

As a measure of the response of the $\mathrm{Pb}, \mathrm{PbO} / \mathrm{ZrO}_{2}$ electrode a series of potentiometric acid-base titrations were performed. The reaction that was followed was

$$
\mathrm{Cr}_{2} \mathrm{O}_{7}=+\mathrm{CO}_{3}=\leftrightharpoons 2 \mathrm{CrO}_{4}=+\mathrm{CO}_{2}
$$

which is, in effect, a titration of the Lux-Flood acid $\mathrm{Cr}_{2} \mathrm{O}_{7}=$ by the base $\mathrm{CO}_{3}=$. This reaction was first studied by Shams el Din who showed it to be uncomplicated 16 . The presence of chromate in the melt appears to have no effert on the titration 17 . In these experiments weighed quantities of vacuumdried reagent grade $\mathrm{Na}_{2} \mathrm{CO}_{3}$ were added to various ratios of $\mathrm{Cr}_{2} \mathrm{O}_{7}-\mathrm{Cr} \mathrm{O}_{4}=$ in $\mathrm{NaNO}_{3}-\mathrm{KNO}_{3}$ at temperatures between $33 \mathrm{~J}-350^{\circ} \mathrm{C}$. The resurise of the $\mathrm{Pb}, \mathrm{PhO} / 7 \mathrm{rO} 2$ electrode for a typical titration at $336^{\circ} \mathrm{C}$ is shown in Figure 3 . The equivalence point is quite sharp and corresponds to a change in potential of about $500 \mathrm{mV}$. The results of three different titration at $336 \pm 2^{\circ} \mathrm{C}$ are given in Tăhle I.

The agreement between the concentration of $\mathrm{Cr}_{2} \mathrm{O}_{7}=$ in the melt and that determined analytically is reasonably good. These experiments indicate that even at temperatures below $350^{\circ} \mathrm{C}$ the $\mathrm{Pb}, \mathrm{PbO} / \mathrm{ZrO}_{2}$ electrode responds rapidly and reproducibly to changes in the oxide ion concentration and that the charge-transfer is reversible. 


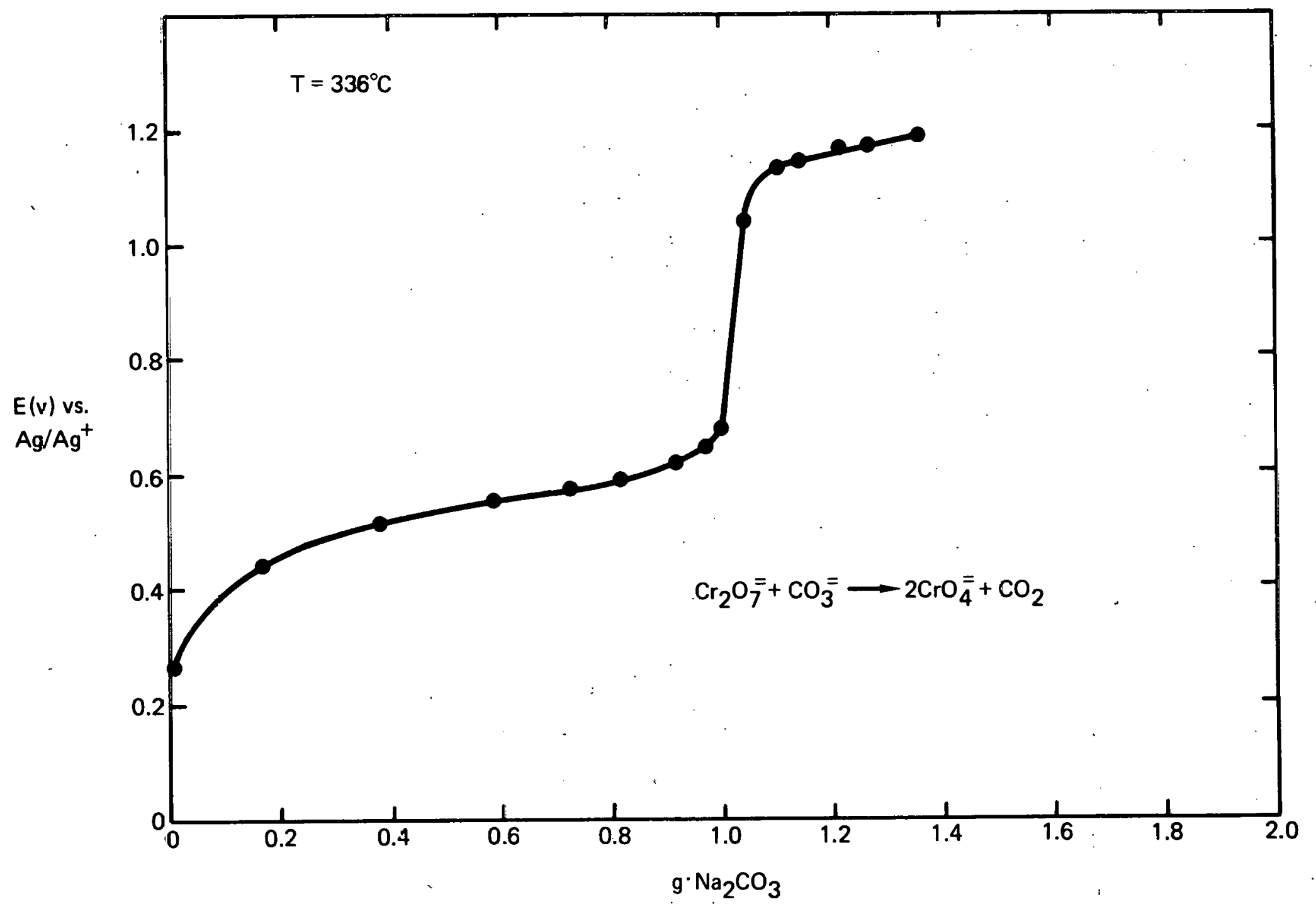

Figure 3. Titration Curve of Dichromate With Carbonate 


\section{TABLE I}

TITRATION OF DICHROMATE WITH CARBONATE IN $\mathrm{NaNO}_{3}-\mathrm{KNO}_{3}$

$$
T=336 \pm 2^{\circ} \mathrm{C}
$$

\begin{tabular}{cccc} 
Exp't. & $\begin{array}{c}{\left[\mathrm{Cr}_{2}{ }_{7}=\right]} \\
\text { added (moles) }\end{array}$ & $\begin{array}{c}{\left[\mathrm{Cr}_{2}{ }_{7}=\right]} \\
\text { found (moles) }\end{array}$ & $\begin{array}{c}\text { Percent } \\
\text { Recovered }\end{array}$ \\
\hline \hline $\mathrm{DN}-1$ & $9.91 \times 10^{-3}$ & $9.86 \times 10^{-3}$ & 99.5 \\
$\mathrm{DN}-2$ & $1.02 \times 10^{-3}$ & $1.00 \times 10^{-3}$ & 98 \\
$\mathrm{DN}-3$ & $1.04 \times 10^{-2}$ & $1.07 \times 10^{-2}$ & 103 \\
\hline
\end{tabular}

Conclusion

The electrode $\mathrm{Pb}, \mathrm{PbO} / \mathrm{ZrO}_{2}\left(\mathrm{Y}_{2} \mathrm{O}_{3}\right)$ has been demonstrated to be sensitive to oxide ion concentrations over the range $10^{-10}$ to $10^{-6} \mathrm{moles} / \mathrm{kg}$ in molten $\mathrm{NaNO}_{3}-\mathrm{KNO}_{3}$ between 336 and $350^{\circ} \mathrm{C}$. Uver this concentration range the concentration dependence of the electrode potential is linear with a slope corresponding to a two-electron process. The response of the $\mathrm{Pb}, \mathrm{PbO} / \mathrm{ZrO}_{2}$ electrode to changes in the oxide ion concentration is very rapid, and once the equilibrium potential has been reached $(-5-10 \mathrm{~min})$ it remains very stable $( \pm 0.0005 \mathrm{~V})$ for as long as 48 hours. 


\section{REFERENCES}

1. R. M. Dell and A. Hooper, "Solid Electrolytes, General Principles Characterization, Material, Applications," P. Hagennuller and W. Van Gool, eds. Academic Press, New York, 1978, p. 292.

2. M. L. Deanhardt and K. H. Stern, J. Phys. Chem., 84, 2831 (1980).

3. K. H. Stern, J. Electrochem. Soc., 127, 2375 (1980).

4. J. H. E. Jeffes and R. Sridhar, "Electromotive Force Measurement in High Temperature Systems," C. B. Alcock, ed., American Elsevier, New York, 1968, p. 199.

5. D. R. Flinn and K. H. Stern, J. Electroanal Chem., 63, 39 (1975).

6. J. 0' M. Bockris and G. W. Mellors, J. Phys. Chem., 60, 1321 (1956).

7. G. Brauer, "Handbook of Preparative Inorganic Chem." Vol. 1, 2nd ed., Academic Press, New York, 1963, p. 975.

8. P. G. Zambonin, J. Electroanal Chem, 45, 451 (1973).

9. J. D. Burke and D. H. Kerridge, Electrochem. Acta, 19, 251 (1976).

10. H. Lux, Z. Electrochem., 45, 303 (1939).

11. H. Flood and T. Forland, Acta Chem. Scand., 1, 592 (1947).

12. R. Kust, Inorg. chem., 6, 2239 (1967).

13. S. N. Flengas and E. Rideal, Proc. Royal Soc., A233, 443 (1956).

14. R. W. Laity in "Reference Electrodes," D. J. G. Ives and G. J. Janz, eds., Academic Press, New York, 1961, p. 585.

15. K. H. Stern, Electrochem. Acta, 24, 509 (1979).

16. A. M. Shams el Din and A. A. A. Gerges, J. Electroanal, Chem., 4, 309 (1962).

17. J. D. Van Norman and R. A. Osteryoung, Anal. Chem., 32, 398 (1960).

18. K. H. Stern, J. Phys. Chem., 72, 1963 (1968).

19. J. D. Van Norman and R. A. Osteryoung, Anal. Chem., 32, 398 (1960).

20. 0. Kubaschewski, E. LL. Evans, and C. B. Alcock," Metallurgical Thermochemistry," 4th ed. Pergamon Press, New York, 1967, p. 426. 
UNL IMITED RELEASE

INITIAL DISTRIBUTION:

Division of Thermal and Mechanical Energy Storage Systems

MS 6B025 Room 1G-100

Forrestal Building

U.S. Department of Energy

Washington, D. C. 20585

Attn: M. Gurevich

S. Strauch

J. H. Swisher

Division of Solar Thermal Energy Systems

U.S. Department of Energy

60U t Street N.W., Rooin 419

Washington, D.C. 20585

Attn: W. Auer

G. W. Braun

K. Cherian

M. U. Gutstein

J. E. Rannels

D. Sehueler

Albuquerque Operations Office

Special Programs Division

U.S. Department of Energy

P. 0. Box 5400

Albuquerque, NM 87115

San Francisco Uperations Office

U.S. Department of Energy

1333 Broadway

Oakland, C.A 94612

Attn: D. Elliott

L. Prince

C. M. Kramer

Code 6130

Naval Research Lab

Washington, D. C. 20375

Dr. Robert A. Osteryoung

Department of Chemistry

State University of New York at Buffalo

Buffalo, NY 14214

Prof. Harald A. Oye

Institutt for uorganisk kjemi

Norges tekniske hogskolc

Universitetet $\mathrm{i}$ Trondheim

N-7034 Trondheim - NTH, NORWAY 
John Neill

Advanced Energy Concepts

Suite I

11722 Sorrento Valley Rd.

San Diego, CA 92121

Aerospace Corporation

2350 El Segundo Blvd.

El Segundo, CA 90009

Attn: P. Mathur

L. R. Sitney

Babcock and Wilcox Company

P. 0. Box 351

Barberton, OH 44203

Attn: William F. Clancey

Murray Wiener, Power Generation Group

Bill Oberjohn

Babcock and Wilcox

Box 835

Alliance, $\mathrm{OH} \quad 44601$

Dr. C. A. Bolthrunis

Badger Energy; Inc.

One Broadway

Cambridge, MA 02142

Robert L. Lessley

Bechtel Corporation

50 Beale St.

San Francisco, CA 94119

James P. Maddox

Biphase Energy Systems

2800 Airport Ave.

Santa Monica, CA 90405

William D. Beverly

Boeing Engineering and Construction Co.

P. 0. Box 3707

Seattle, WA 98124

George H. Rowe

Combustion Enginecring

1000 Prospect Hill Road

Windsor, CT 06095

Pierre Spiteri

EDF

Les Renaidierz

Ecuelles, France 
Sydney H. White

EIC Labs., Inc.

55 Chapel Street

Newton, MA 02158

Electric Power Research Institute

P. 0. Box 10412

3412 Hillview Ave.

Palo Alto, CA 94303

Attn: J. Bigger

T. R. Schneider

Donald C. Erickson

Energy Concepts Co.

627 Ridyely

Annapolis, MD 21401

T. V. Narayanan

Foster Wheeler

12 Peach Tree Hill Ruad

Livingston, NJ 07039

Donald J. Spellman

Gas Cooled Reactor Assoc. 3344 N. Torrey Pines Road

La Jolla, CA 92137

General Atomic Co.

P. 0. Box 81608

San Dteyu, CA 92138

Attn: Thomas H. Van Hagan

Daniel L. Vrable

Fred F. Witt

General Electric

3172 Porter Drive

Palo Alto, CA 94304

Soeren S. Nielsen

Gould, Inc.

40 Gould Center

Rolling Meadows, IL 60008

Alan Snelson

ITT Research Institute

10 W 35 Street

Chicago, IL 60616

Jet Propulsion Lahoratory

4800 0ak Grove Dr.

Pasadena, CA 91103

Attn: J. Becker

R. Manvi

J. Sheldon

V. Truscello 
Skip Gross

MSA Research

Evans City, PA 16033

Martin Marietta Corporation

Box 179

Denver, CO 80201

Attn: Charles N. Bolton Russell A. Chihoski David W. Neiswander Tom Tracey

McDonnel 1 Douglas

5301 Bolsa Ave.

Huntington Beach, CA 92647

Attn: Donald L. Endicott George F. Greenwald Russell T. Neher

J. H. DeVan

Oak Ridge National Laboratory

Oak Ridge, 'TN 37830

01 in Corporation

275 Winchester. Ave.

New Haven, CT 06511

Attn: Louis C. Fiorucci

Stephen L. Goldstein

Joe K. Mensah

01 in Corporation

120 Long Ridge Road

Stamford, CT 06904

Attn: Norman Christopher

Gerald A. Habib

Robert E. Smith

Pacific Gas and [lectric

3400 Crow Canyon Road

San Ramon, CA 94583

Attn: Helena T. Rowland

Jay Raggio

Harold E. Seielstand

Dr. R. W. Foreman

Park Chemical Company

8074 Military Averue

Detroit, MI 48204

Richard D. Smith

Rocket Research Company

York Center

Redmond, WA 98052 
Robert J. Walter

Rocketdyne

6633 Canoga Ave.

Canoga Park; CA 91360

Rockwell International/ETEC

8900 De Soto Ave.

Canoga Park, CA 91304

Attn: Jerry B. Brukiewa, ETEC

A. Z. Frangos

Rick L. Howerton, ETEC

Ted Johnson, ESG

Solar Energy Research Institute

1536 Cole Blvd.

Golden, CO 80401

Attn: B. Butler

B. P. Gupta

R. G. Nix

R. Orli $<$ (Libirary)

P. A. Roberts

P. Russell

K. Touryan

C. Wyman

George Yenetchi

Solar Thermal Systems

nivision of Exxon Enterprises, Inc. P. 0. Box 592

Florham Park, NJ 07932

Kenneth Ladd

Southwestern Public Service Co.

P. 0. Box 1261

Amarillo, TX 79170

Donald J. Liffengren

Stearns-Roger

4500 S. Cherry Creek Drive

Denver, CO 80217

Robert M. N. Killen

United Engineers and Construction

Suit.e 300

3344 N. Torrey Pines CT.

La Jolla, CA 92137

John B. Mulligan

United Engineers and Construction

30 S. 17th Street

Philadelphia, PA 19103 
Niven D. Morgan, Jr.

Vertac Chemical Corporation

Suite 241

3000 Knight Office Place

Shreveport, LA 71105

Stuart A. Shiels

Advanced Reactors Division

Westinghouse Electric Corporate

Box 158

Madison, PA 15663

C. Winter, 400

H. J. Saxton, 2520

R. A. Guidotti, 2523

A. Narath, 4000

J. H. Scott, 4700

G. E. Brandvold, 4710; Attn: B. W. Marshall, 4713

R. P. Stromberg, 4714

V. L. Dugan, 4720; Attn:

J. V. Otts, 4721

J. F. Banas, 4722

J. K. Galt, 5000

J. A. Leonard, 4725

J. E. Schirber, 5150

R. M. Biefeld, 5154

G. D. Stucky, 5154

R. S. Claassen, 5800

R. G. Kepler, 5810

M. J. Davis, 5830

M. M. Karnowsky, 5832

J. W. Mumford, 5832

R. W. Rohde, 5832

N. J. Magnani, 5840 ; Attn: D. W. Schaefer, 5841

T. B. Cook, 8000

W. E. Al zheimer, 8120; Attn: R. J. Gallagher, 8124

A. N. Bl ackwell, 8200

B. F. Murphey, 8300

D. M. Schuster, 8310

R. W. Bradshaw, 8313

R. W. Mar, 8313

D. A. Nissen, 8313

S. H. Goods, 8316

J. C. Swearengen, 8316

R. Rinne, 8320; Attn: C. F. Melius, 8326

L. Gutierrez, 8400

R. Baroody, 8410

R. C. Wayne, 8430

C. S. Selvage, 8450

P. J. Eicker, 8451

A. C. Skinrood, 8452

R. W. Carling, 8453 (25)

L. G. Radosevich, 8453

W. G. Wilson, 8453 
C. M. Tapp, 8460

Publications Division, 8265, for TIC (27)

Publications Division, 8265/Technical Library Processes Division, 3141

Technical Library Processes Division, 3141

M. A. Pound, 8214, for Central Technical Files (3) 


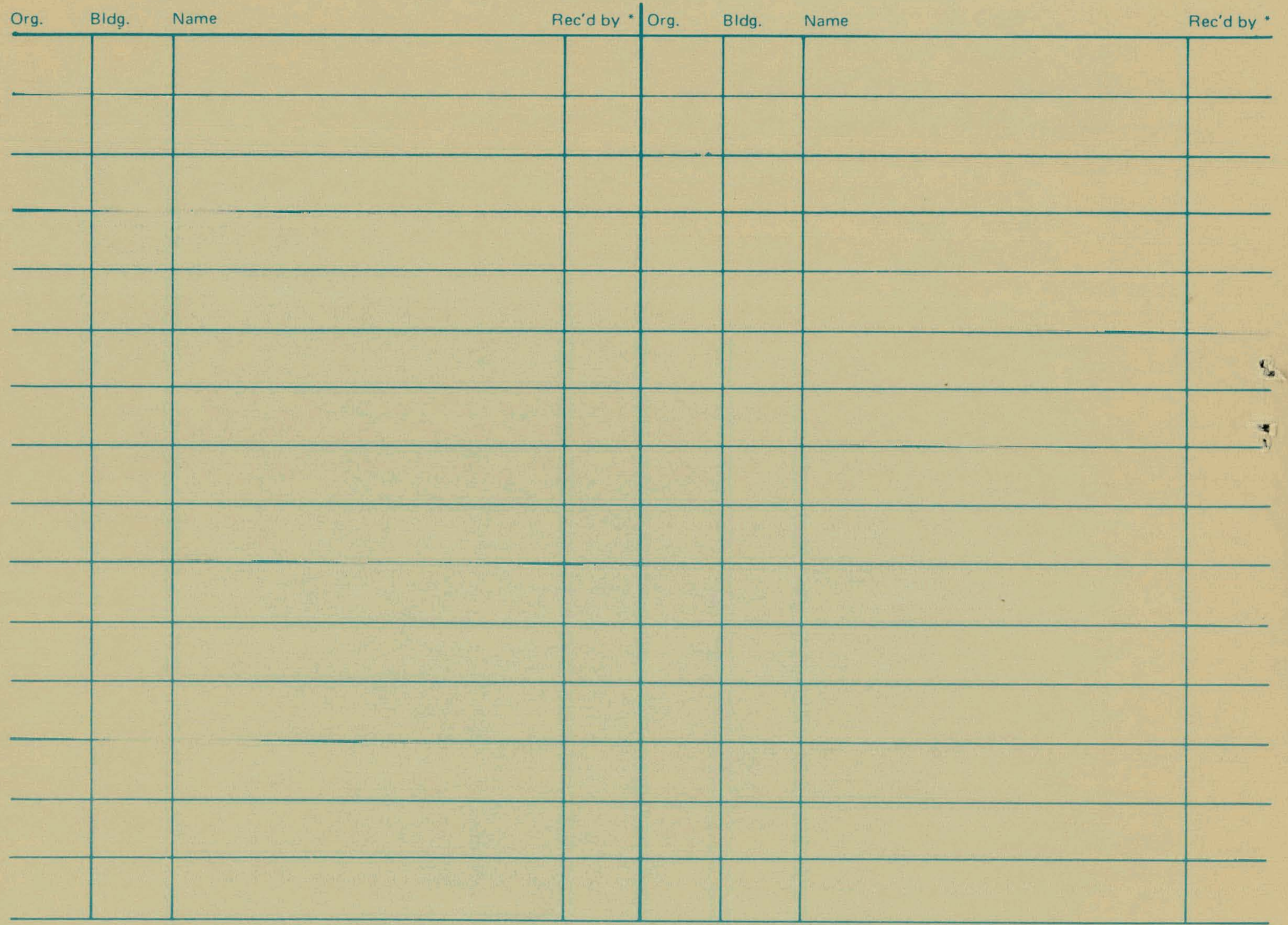

